\title{
Proposed trade agreement could increase patent protection for pharmaceuticals
}

$\mathrm{O}$ xfam Canada is calling on Ottawa to oppose any provisions in a new trade agreement that would increase patent protection for major pharmaceutical companies and restrict access to desperately needed medications in Vietnam and Peru, the poorer countries participating in the negotiations.

Oxfam, Médecins Sans Frontières and the Council of Canadians are concerned about aggressive patent protections the United States is seeking in the Trans-Pacific Partnership, a multilateral trade agreement. The US, Canada, Australia, Brunei Darussalam, Chile, Malaysia, Mexico, New Zealand, Peru, Singapore and Vietnam are trying to reach a deal that would lower tariffs and other barriers to ease the flow of goods, people, services, capital and data across borders. Japan is set to join the talks in July.

"We want to ensure that Canada is on the side of ensuring that the developing countries in the agreement can exercise all of the rights and safeguards they [currently] have," says Mark Fried, Oxfam Canada's policy coordinator.

Talks enter their 17th round of negotiations May 15-24 in Lima, Peru, where 20 working groups will try to hammer out agreements on different chapters, including intellectual property.

Although the negotiations are shrouded in secrecy, leaked versions of an early text (http://keionline.org/node /1091) indicate the Office of the United States Trade Representative wants this deal to override public health provisions currently granted to countries participating in the 2001 World Trade Organization's Doha Declaration on the TRIPS (Trade-Related Aspects of Intellectual Property Rights) Agreement and Public Health. These protections are also outlined in the 2008 World Health Organization Global Strategy and Plan of Action on Public Health, Innovation, and Intellectual Property.

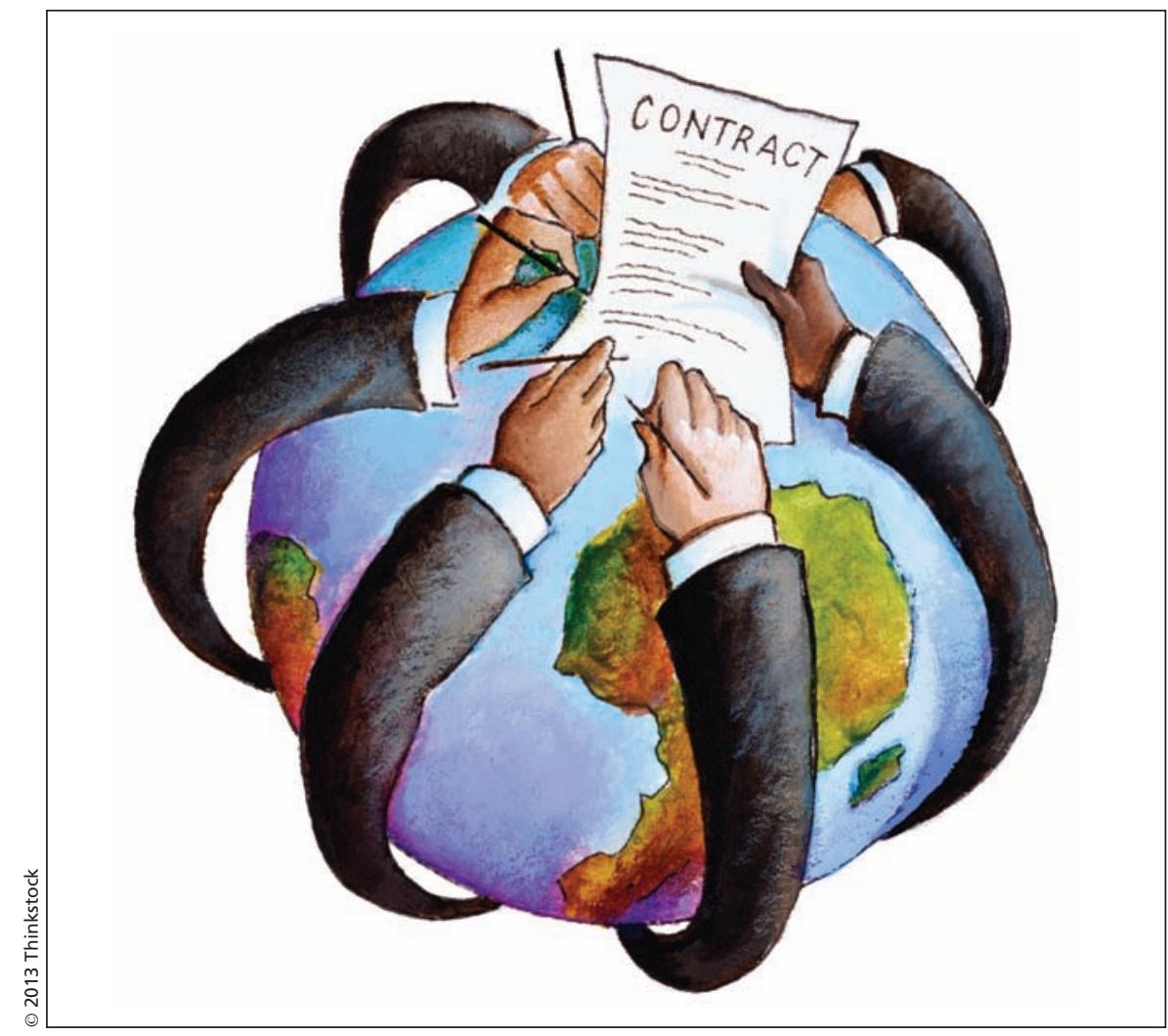

The proposed Trans-Pacific Partnership, a multilateral trade agreement, contains intellectual property-related proposals that are more stringent than those required by the World Trade Organization.

Those agreements affirmed the rights of member states to circumvent patent protection if necessary to protect public health and secure access to essential medicines.

"A series of proposals has been put forward by the United States for the [Trans-Pacific Partnership] agreement, which would impact the price of medicines," says Fried. "These are intellectual property-related proposals, which would impose on the signatories of this agreement [new] obligations that are more stringent than those required by the World Trade Organization."

For example, the US is proposing that generic companies would not be granted access to the clinical trial data that brand-name pharmaceutical companies submit to license a drug. That would mean generic companies would have to conduct their own research, adding years to the process of getting their generic products approved.

While the Department of Foreign Affairs and International Trade would not comment specifically on its negotiating position, a spokesperson says Canada "supports and promotes the flexibilities that the WTO [World Trade Organization] has provided to members in implementing the TRIPS Agreement."

"With respect to intellectual property protection in the pharmaceutical sector, the government of Canada has always sought to strike a balance between promoting innovation and job creation and ensuring that Canadians continue to have access to the affordable drugs 
they need, and will continue to do so in the TPP [Trans-Pacific Partnership]," Janiece Walsh wrote in an email to CMAJ.

The US has proposed that any delay in processing an application for a patent would be added on to the end of its 20year lifespan, increasing the length of patent protection.

Regardless of what the US is seeking for intellectual property, it will only succeed if Canada and other participating countries are satisfied with what they get in return, says Michael Hart, who holds the Simon Reisman chair in trade policy at Carleton University's Norman Paterson School of International Affairs in Ottawa, Ontario. Hart was previously a trade policy expert and negotiator with the Department of Foreign Affairs and International Trade.
So far, the US Congress has not given the US Trade Representative authority to negotiate without amending the deal once it comes to Congress for approval - a key step US free trade and NAFTA negotiators had to secure in the past to persuade other countries that is was worthwhile entering a deal. Otherwise, even if negotiating countries reach a consensus, Congress could refuse to pass the Trans-Pacific Partnership (TPP) without amendments, essentially sending negotiators back to the drawing board.

"My view on these negotiations is they are of interest to Canada only as a placeholder in the event that some bigger, more important countries join in," says Hart. "We have a free trade agreement with the Americans and the Mexicans. It would be nice to add Australia and New Zealand to that, but trade isn't very big with them ... it's a relatively small gain. If the Chinese were to join in, then it would potentially be a big thing, but then I think the agenda has to be something different."

Negotiators have said the agreement could ultimately include all 21 members of the Asia-Pacific Economic Cooperation organization, but so far China is not involved in the talks.

In a statement made when Ottawa entered the negotiations, the federal government said the TPP would open new markets and increase Canadian exports to the region, which represents more than 658 million people and a combined Gross Domestic Product of $\$ 20.5$ trillion.

The deal is supposed to be concluded by October 2013. —Laura Eggertson, CMAJ

CMAJ 2013. DOI:10.1503/cmaj.109-4490 